\title{
Investigation of surface defects and apparel manufacturing efficiency of fabrics woven from recycled cotton and blends
}

\author{
DOI: $10.35530 / I T .071 .03 .1639$
}

KALKANCI MIHRIBAN

\section{ABSTRACT - REZUMAT}

\section{Investigation of surface defects and apparel manufacturing efficiency of fabrics woven from recycled cotton and blends}

For a sustainable life, new strategies have come to the forefront relating to design, production and recycling processes in textiles and apparel manufacturing industries. In this study, woven fabrics consisting of weft threads from recycled cotton fiber, original cotton fiber and original polyester fiber (35\%/65\% polyester/recycled cotton, 35\%/65\% polyester/original cotton) were made to order in a textile firm and have been investgated in terms of surface defects and apparel manufacturing efficiency. The types and numbers of defects obtained during inspection were recorded and evaluated by using Pareto analysis. The percentage of surface/fabric defective products in all defects is $78.57 \%$ for $35 \% / 65 \%$ polyester-recycled cotton fabrics and $69.09 \%$ for that in $35 \% / 65 \%$ polyester-original cotton fabrics. The percentage of second quality products at the end of apparel manufacturing is $4.9 \%$ for recycled cotton fabric products and $2.75 \%$ for original cotton fabrics.

Keywords: recycled fabric, fabric quality, second quality, wastage, apparel manufacturing efficiency

\section{Analiza defectelor de suprafață și a eficienței producției de îmbrăcăminte pentru țesăturile din bumbac reciclat și în amestec}

Pentru o dezvoltare durabilă, noi strategii sunt implementate privind procesele de proiectare, producție și reciclare în industria textilă și de îmbracăminte. În acest studiu, țesăturile realizate din bumbac reciclat, bumbac original și poliester original (35\%/65\% poliester/bumbac reciclat, 35\%/65\% poliester/bumbac original) au fost utilizate într-o companie producătoare de îmbrăcăminte și au fost analizate, în ceea ce privește defectele de suprafață și eficiența producției. Tipurile și numărul de defecte identificate în timpul inspecției au fost înregistrate și evaluate utilizând analiza Pareto. Procentul de produse cu defecte de suprafață din totalul defectelor este de $78,57 \%$, pentru țesăturile din $35 \% / 65 \%$ poliester/bumbac reciclat și 69,09\% pentru țesăturile din 35\%/65\% polyester/bumbac original. Procentul de produse de calitatea a doua, la sfârșitul producției de îmbrăcăminte este de 4,9\% pentru produsele din țesături din bumbac reciclat și de 2,75\% pentru țesăturile din bumbac original.

Cuvinte-cheie: țesătură reciclată, calitatea țesăturii, calitatea a doua, deșeuri, eficiența producției de îmbrăcăminte

\section{INTRODUCTION}

The recycling issue has come into prominence due to exhaustion of natural sources as well as the fact that textiles is an industry that is harmful for the environment. Other environmentally-friendly applications in textiles are carried out with strategies including "clean production", "recover/reuse", "reduction of waste in the first place", "product modification", "recycle", "energy recovery", and "waste utilization". Because of great production volumes, approximately one million tons of waste are generated in Turkey by the textile industry each year. If total recovery would be possible, this would be equal to $17 \%$ of annual national unginned cotton [2]. It is quite difficult to investigate recycling in textile production issue under one title because raw material, machinery, energy types and costs, environmental interactions during processes and recyclability of products are not the same [3]. Recycling is mostly carried out during spinning. Open end spinning utilizes recycled fibers in great ratios, as the open-end rotor spinning method allows use of shorter fibers compared to ring spinning [4].

However, the wastes that are generated in the end of apparel manufacturing processes are fabric roll start and end pieces (approximately 15\% of whole fabric), spread cutting leftovers, and defective fabric pieces [3]. The wastage ratios of carded yarn production is $5.5-10.5 \%$, combed yarn production is $12 \%$, and this ratio approaches $23 \%$ at fabric and apparel manufacturing steps [5]. Significant raw material recovery can be achieved, if the wastes of the apparel manufacturing and spinning are utilized.

There are different methods of recycling including product recovery, chemical recovery and thermal recovery [6]. The structural and mechanical properties of fabrics produced from textile wastes, and their utilization areas [7-11], the utilization potential of polyester/cotton blend fabrics in composite materials [12] and production possibilities and production parameters of recycled yarns [13-18] have been the subjects of recent studies. However, studies relating 


\begin{tabular}{|c|c|c|c|c|c|c|c|}
\hline \multicolumn{8}{|c|}{ FABRIC PROPERTIES } \\
\hline \multirow{2}{*}{$\begin{array}{c}\text { Order } \\
\text { number }\end{array}$} & \multirow{2}{*}{$\begin{array}{l}\text { Weft thread } \\
\text { raw material }\end{array}$} & \multirow{2}{*}{$\begin{array}{c}\text { Weft thread } \\
\mathrm{Ne}\end{array}$} & \multicolumn{2}{|c|}{ Density (thread/cm) } & \multirow{2}{*}{$\begin{array}{c}\text { Weight } \\
\left(\mathrm{g} / \mathrm{m}^{2}\right)\end{array}$} & \multirow{2}{*}{$\begin{array}{c}\text { Roll } \\
\text { number }\end{array}$} & \multirow{2}{*}{$\begin{array}{c}\text { Total } \\
\text { (m) }\end{array}$} \\
\hline & & & Warp & Weft & & & \\
\hline 1 & $35 \%$ PES-65\% r-Cotton & $20 / 1$ & 30 & 25 & 100 & 9 & 2372 \\
\hline 2 & $35 \%$ PES-65\% Cotton & $20 / 1$ & 30 & 25 & 100 & 8 & 2360 \\
\hline
\end{tabular}

to the defects of fabrics produced from recycled fibers and their effect on the apparel manufacturing are not sufficient.

Defect formation during woven fabric production is inevitable regardless of the raw material. In the studies which have been conducted in toweling fabric [19] and apparel fabric [20,21] weaving factories in order for determination and statistical evaluation of fabric defects, it was reported that $95 \%$ of problems which occur due to fabric defects can be solved by means of seven technical methods. These methods are flow chart, check sheet, cause effect diagram, histogram, scatter diagram, and control cards [22-23]. Woven fabric defects are deviations, which occur regionally, affect fabric appearance, change fabric structure and cause special changes in regional limitation [24]. Fabric defects have been defined by Turkish Standards Institute as "defects in fabrics which are caused by the yarn, auxiliary material, labor, machinery, equipment or working method, and can be seen and evaluated with eye and impair fabric appearance" [25].

In this study, it was aimed to determine and define defects that can be encountered on fabrics in a factory, which produces shirting fabrics from yarns of recycled cotton fibers and their blends (regenerated yarns, as known in the industry). The most common defects were investigated through Pareto analysis among statistical process control methods. Following, the efficiency of two fabrics made to order were compared by investigating defective pieces generated during sorting processes in apparel manufacturing and second-quality product amount formed at the end of production.

\section{MATERIAL and METHOD}

\section{Material}

The study has been carried out at a factory of yarnweaving (315 weaving machines) in Denizli (Turkey). This study has been conducted in a factory, located in Denizli province, (consisting of spinning and weaving mills), which has 315 weaving machines and produces home textiles (such as bedlinens) -, shirting, trouser and clothing fabrics. In the study, white shirting fabrics (weft threads of $35 / 65 \%$ polyester/recycled cotton and $35 / 65 \%$ polyester/original cotton) produced for two women's shirt orders were investigated. The warp thread was 100-denier polyester yarn for all fabrics which were woven with plain weave repeat. The recycled yarns were produced in the open-end spinning section of the mentioned factory. The recycled fibers were obtained from Uşak province. The length of the polyester staple fiber is $38 \mathrm{~mm}$. In woven fabrics, both weft and warp threads influence the physical and mechanical properties of the fabrics. In the industry, polyester fibers are preferred in blends for avoiding problems that can occur due to recycled yarns. In this study, no changes have been made in warp density and type. On the other hand, only changes to weft threads were made. In table 1 , the density and weight values of fabrics that were produced for orders are shown.

\section{Method}

Woven raw fabrics were investigated manually by using a light board. The controls were carried out on the raw fabric. Pareto analysis, among statistical process control methods, was used for statistical analysis of defect numbers obtained from the fabric inspection.

The defects that are classified in fabric inspection sheets used in the current study can be grouped in three main classes; defects in weft direction, defects in warp direction and other defects. The defects in weft direction are full-width double wefts, half-width double wefts, full-width broken weft, half-width broken weft, stop mark, weft fiber in color, soiledgreased weft, thin-thick weft, excessive weft density. The defects in warp direction are broken warp, excessive warp density, loose-tight warp, warp fiber in color, stained-greased warp, thin thick warp, double warps, missing warp, temple mark; and other defects include hole/tear/burst, slub, bad selvedge, knot, batch difference, and ripple effect.

All fabrics are received to the factory in two batches and in white color. Shirts were cut and sewn in the apparel supplier of the factory in Denizli. Apparel manufacturing processes have been carried out and then apparel manufacturing efficiency, and second quality ratios were determined.

\section{FINDINGS AND DISCUSSION}

\section{Woven fabric defect numbers and Pareto} analysis

In table 2, the width, length and grams per square information of fabrics produced for the orders are shown. According to this, 9 rolls from the 35\% PES $65 \%$ r-Cotton fabric, and 8 rolls from the 35\% PES $65 \%$ Cotton fabric were investigated.

In total, 2372 meters of $35 \%$ PES - 65\% r-Cotton and 2360 meters of $35 \%$ PES and $65 \%$ Cotton fabrics woven for orders were investigated and the obtained 


\begin{tabular}{|c|c|c|c|c|c|c|c|c|c|}
\hline \multicolumn{10}{|c|}{ STRUCTURAL PROPERTIES OF THE INVESTIGATED FABRICS } \\
\hline \multicolumn{10}{|c|}{$35 \%$ PES $-65 \%$ r-Cotton fabrics } \\
\hline Fabric roll number & 1 & 2 & 3 & 4 & 5 & 6 & 7 & 8 & 9 \\
\hline Fabric roll length $(\mathrm{m})$ & 347 & 248 & 150 & 222 & 373 & 286 & 276 & 175 & 295 \\
\hline Fabric roll width (cm) & 159 & 160 & 161 & 159.5 & 160 & 160 & 161 & 160 & 160 \\
\hline Weight $\left(\mathrm{g} / \mathrm{m}^{2}\right)$ & 103 & 110 & 109 & 105 & 101 & 100 & 102 & 109 & 105 \\
\hline \multicolumn{10}{|c|}{$35 \%$ PES $-65 \%$ Cotton fabrics } \\
\hline Fabric roll number & 1 & 2 & 3 & 4 & 5 & 6 & 7 & \multicolumn{2}{|c|}{8} \\
\hline Fabric roll length $(\mathrm{m})$ & 228 & 293 & 305 & 345 & 380 & 253 & 246 & \multicolumn{2}{|c|}{310} \\
\hline Fabric roll width $(\mathrm{cm})$ & 160 & 159.5 & 160 & 160 & 159.5 & 160 & 160 & \multicolumn{2}{|c|}{161} \\
\hline Weight $\left(\mathrm{g} / \mathrm{m}^{2}\right)$ & 102 & 100 & 103 & 101 & 101 & 100 & 109 & \multicolumn{2}{|c|}{104} \\
\hline
\end{tabular}

fabric defects were recorded in inspection sheets. The defects in the outermost 3 centimeters of fabric width were ignored. In case there are more than one defects in a running meter of the fabric, the defect with the highest penalty points was recorded into the control card. Pareto analysis, among statistical process control methods, was used for the statistical analysis of the defect numbers obtained from the fabric inspection.

The numbers of defects obtained from $35 \%-65 \%$ $r$-Cotton fabric rolls are given in table 3. Accordingly, the total number of defects obtained from 9 rolls is 293 . The numbers of defects obtained from $35 \%-65 \%$ Cotton fabric rolls are given in table 4 . Accordingly,

Table 3

\begin{tabular}{|c|c|c|c|c|c|c|c|c|c|}
\hline \multicolumn{10}{|c|}{ NUMBERS OF DEFECTS FOUND ON 35\% PES-65\% R-COTTON FABRIC ROLLS } \\
\hline Defect name & 1st roll & 2nd roll & 3rd roll & 4th roll & 5th roll & 6th roll & 7th roll & 8th roll & 9th roll \\
\hline Full-width double wefts & 5 & 3 & 2 & 2 & 4 & 2 & 6 & 1 & 3 \\
\hline Double wefts half-width or less & 3 & & 3 & 3 & 4 & 2 & 2 & 2 & 2 \\
\hline Full-width broken weft & & & & & 1 & & & & \\
\hline Half-width broken weft & 7 & 3 & 4 & 3 & 7 & 8 & 7 & 8 & 8 \\
\hline Stop mark & 5 & 4 & 2 & 4 & 5 & 3 & 6 & 2 & 4 \\
\hline Fiber in color & 3 & & & 1 & 4 & & 3 & & 1 \\
\hline Soiled-greased weft & & & 2 & & 3 & & 5 & & \\
\hline Thin-thick weft & 4 & 3 & & 3 & 5 & & & 3 & \\
\hline Excessive weft density & & & & & & 2 & & & \\
\hline Broken warp & 4 & 4 & 3 & 6 & 5 & 4 & 4 & 2 & 1 \\
\hline Excessive warp density & & & & 1 & & & 1 & 1 & 1 \\
\hline Tight-loose warp & & & & & 2 & & & & \\
\hline Drawing-in defect & & & & 1 & & & & 1 & \\
\hline Lattice & & & 1 & & & & & & \\
\hline Warp fiber in color & 1 & & & & & & & & \\
\hline Soiled-greased warp & & 1 & 1 & 2 & 3 & 1 & & 3 & \\
\hline Thin thick warp & & & & & & 1 & & & \\
\hline Double warps & & & & & & 1 & & & \\
\hline Missing warp & & & & & & 1 & & & \\
\hline Temple mark & & & & & 1 & & & & \\
\hline Hole-tear-burst & & & 1 & & & & & & \\
\hline Slub & & 1 & & 4 & 6 & & 1 & 4 & 1 \\
\hline Bad selvedge & 1 & 3 & & & 1 & 4 & 4 & & 4 \\
\hline Knot & & & & 3 & 1 & 1 & 1 & 3 & 1 \\
\hline Soil grease stain & & 2 & & & 3 & & 2 & & 1 \\
\hline Number of defects in the roll & 33 & 24 & 19 & 33 & 55 & 30 & 42 & 30 & 27 \\
\hline Total defect number & & & & & 293 & & & & \\
\hline
\end{tabular}




\begin{tabular}{|c|c|c|c|c|c|c|c|c|}
\hline \multicolumn{9}{|c|}{ NUMBERS OF DEFECTS FOUND ON 35\% PES-65\% COTTON FABRIC ROLLS } \\
\hline Defect name & 1st roll & 2nd roll & 3rd roll & 4th roll & 5th roll & 6th roll & 7th roll & 8th roll \\
\hline Full-width double wefts & 1 & 1 & 2 & 2 & 3 & 5 & 1 & 2 \\
\hline Double wefts half-width or less & & 2 & 2 & 3 & 4 & 2 & 2 & 3 \\
\hline Full-width broken weft & & 1 & & & 1 & & & \\
\hline Half-width broken weft & 1 & 2 & 1 & 1 & 1 & 1 & 3 & 2 \\
\hline Stop mark & 4 & 4 & 2 & 4 & 5 & 3 & 2 & 2 \\
\hline \multicolumn{9}{|l|}{ Fiber in color } \\
\hline Soiled-greased weft & & & & & 3 & 1 & & 2 \\
\hline Thin-thick weft & 1 & & & 3 & 2 & & 3 & \\
\hline Excessive weft density & & & 1 & & & & & \\
\hline Broken warp & 4 & 2 & 1 & 8 & 5 & 4 & 1 & 3 \\
\hline Excessive warp density & & 1 & 1 & 1 & & 1 & 1 & \\
\hline Tight-loose warp & & & & 2 & & & & \\
\hline Drawing-in defect & & & & 1 & & & 1 & \\
\hline Lattice & & & & & & & & 1 \\
\hline Warp fiber in color & & & 1 & & & & & \\
\hline Soiled-greased warp & 1 & & & 2 & 4 & & 3 & 1 \\
\hline Thin thick warp & & & & 1 & & & & \\
\hline Double warps & & & 1 & & & & & \\
\hline Missing warp & 1 & & & & & & & \\
\hline Temple mark & & & & & 1 & & & \\
\hline Hole-tear-burst & & & & & & & & 1 \\
\hline Slub & 1 & 2 & 1 & 5 & 7 & 1 & 4 & \\
\hline Bad selvedge & 3 & 4 & 4 & & 1 & 4 & & \\
\hline Knot & & 1 & 1 & 3 & 1 & 1 & 3 & \\
\hline Soil grease stain & 2 & 1 & 1 & & 3 & 2 & & \\
\hline Number of defects in the roll & 19 & 21 & 19 & 36 & 41 & 25 & 24 & 17 \\
\hline Total defect number & & & & 2 & & & & \\
\hline
\end{tabular}

the total number of defects obtained from 8 rolls is 202.

In the defect report sheet, the defects are listed in descending order in terms of their numbers, and defect percentages and cumulative rates are given as in table 5.

Among the 25 woven fabric defects obtained from $35 \%-65 \%$ r-Cotton fabric rolls, the Pareto diagram shown in figure 1 has been arranged in order to determine $80 \%$ of the defects based on data gathered from table 5. In the conducted Pareto analysis, it was seen that half-width broken weft $(18.77 \%)$, stop mark $(11.95 \%)$, broken warp $(11.26 \%)$, full-width weft $(8.42 \%)$, double wefts half width or less $(7.17 \%)$, thin-thick weft $(6.14 \%)$, slub $(5.80 \%)$, bad selvedge $(5.80 \%)$, fiber in color $(4.10 \%)$ which take the highest 9 ranks constitute $80.55 \%$ of all defects.

Among the 25 woven fabric defects obtained from $35 \%$ PES - 65\% Cotton fabric rolls, the Pareto diagram shown in figure 2 has been arranged in order to determine $80 \%$ of the defects based on data gathered from table 5 . In the conducted Pareto analysis, it was seen that broken warp $(13.86 \%)$, stop mark $(12.87 \%)$, slub $(10.40 \%)$, double wefts half-width or less $(8.91 \%)$, full-width double wefts $(8.42 \%)$, bad selvedge $(7.92 \%)$, half-width broken weft $(5.94 \%)$, soiled greased warp $(5.45 \%)$, knot $(4.95 \%)$ which take the highest 9 ranks constitute $78.71 \%$ of all defects.

For the two fabric groups, if the first nine of twentyfive defect types can be avoided, it may be possible to decrease wastage amount by $80 \%$.

When table 5, figures 1 and 2 are investigated, it will be seen that the rankings of defect types are different in 35\% PES-65\% r-Cotton and 35\% - 65\% Cotton fabrics. The half-width broken weft defect, which ranks the first and constitutes $18.77 \%$ of all defects in the $35 \%$ PES-65\% r-Cotton fabric occurred due to the production method of the recycled cotton thread or fiber content. In the original fabrics, half-width broken weft defect descends to the seventh rank with a percent of $5.94 \%$. It is thought that the strength of weft threads decreases due to the fiber quality in the recycled yarns and this leads to weft breaks. Ersoy and Şenol reported in their study, related to yarn production from recycled fibers, that variations in mass per unit length increases based on yarn formation at high rotor speed and; hence, unevenness value 


\begin{tabular}{|c|c|c|c|c|c|c|c|c|}
\hline \multicolumn{9}{|c|}{ DISTRIBUTION OF DEFECTS IN THE FABRICS } \\
\hline \multirow{2}{*}{$\begin{array}{l}\text { Defect } \\
\text { order }\end{array}$} & \multicolumn{4}{|c|}{$35 \%$ PES $-65 \%$ r-Cotton fabrics } & \multicolumn{4}{|c|}{$35 \%$ PES $-65 \%$ Cotton fabrics } \\
\hline & $\begin{array}{l}\text { Defect } \\
\text { name }\end{array}$ & $\begin{array}{l}\text { Number } \\
\text { of defect }\end{array}$ & $\begin{array}{l}\text { Defect } \\
\text { percent }\end{array}$ & $\begin{array}{c}\text { Cumulative } \\
\text { percent }\end{array}$ & $\begin{array}{l}\text { Defect } \\
\text { name }\end{array}$ & $\begin{array}{l}\text { Number } \\
\text { of defect }\end{array}$ & $\begin{array}{l}\text { Defect } \\
\text { percent }\end{array}$ & $\begin{array}{c}\text { Cumulative } \\
\text { percent }\end{array}$ \\
\hline 1 & $\begin{array}{l}\text { Half-width broken } \\
\text { weft }\end{array}$ & 55 & 18.77 & 18.77 & Broken warp & 28 & 13.86 & 13.86 \\
\hline 2 & Stop mark & 35 & 11.95 & 30.72 & Stop mark & 26 & 12.87 & 26.73 \\
\hline 3 & Broken warp & 33 & 11.26 & 41.98 & Slub & 21 & 10.40 & 37.13 \\
\hline 4 & $\begin{array}{l}\text { Full-width double } \\
\text { wefts }\end{array}$ & 28 & 9.56 & 51.54 & $\begin{array}{l}\text { Double wefts } \\
\text { half-width or less }\end{array}$ & 18 & 8.91 & 46.04 \\
\hline 5 & $\begin{array}{l}\text { Double weft half } \\
\text { width or less }\end{array}$ & 21 & 7.17 & 58.7 & $\begin{array}{l}\text { Full-width double } \\
\text { wefts }\end{array}$ & 17 & 8.42 & 54.46 \\
\hline 6 & Thin thick weft & 18 & 6.14 & 64.85 & Bad selvedge & 16 & 7.92 & 62.38 \\
\hline 7 & Slub & 17 & 5.8 & 70.65 & $\begin{array}{l}\text { Half-width broken } \\
\text { weft }\end{array}$ & 12 & 5.94 & 68.32 \\
\hline 8 & Bad selvedge & 17 & 5.8 & 76.45 & $\begin{array}{l}\text { Soiled-greased } \\
\text { warp }\end{array}$ & 11 & 5.45 & 73.76 \\
\hline 9 & Fiber in color & 12 & 4.1 & 80.55 & Knot & 10 & 4.95 & 78.71 \\
\hline 10 & $\begin{array}{l}\text { Soiled greased } \\
\text { warp }\end{array}$ & 11 & 3.75 & 84.3 & Thin thick weft & 9 & 4.46 & 83.17 \\
\hline 11 & $\begin{array}{l}\begin{array}{l}\text { Soiled greased } \\
\text { weft }\end{array} \\
\end{array}$ & 10 & 3.41 & 87.71 & Soil grease stain & 9 & 4.46 & 87.62 \\
\hline 12 & Knot & 10 & 3.41 & 91.13 & $\begin{array}{l}\text { Soiled greased } \\
\text { weft }\end{array}$ & 6 & 2.97 & 90.59 \\
\hline 13 & Soil grease stain & 8 & 2.73 & 93.86 & $\begin{array}{l}\text { Excessive warp } \\
\text { density }\end{array}$ & 5 & 2.48 & 93.07 \\
\hline 14 & \begin{tabular}{|l}
$\begin{array}{l}\text { Excessive warp } \\
\text { density }\end{array}$ \\
\end{tabular} & 4 & 1.37 & 95.22 & $\begin{array}{l}\text { Full-width broken } \\
\text { weft }\end{array}$ & 2 & 0.99 & 94.06 \\
\hline 15 & $\begin{array}{l}\text { Excessive weft } \\
\text { density }\end{array}$ & 2 & 0.68 & 95.9 & Loose-tight warp & 2 & 0.99 & 95.05 \\
\hline 16 & Thin thick warp & 2 & 0.68 & 96.59 & Drawing-in defect & 2 & 0.99 & 96.04 \\
\hline 17 & Drawing-in defect & 2 & 0.68 & 97.27 & $\begin{array}{l}\text { Excessive weft } \\
\text { density }\end{array}$ & 1 & 0.50 & 96.53 \\
\hline 18 & Lattice & 1 & 0.34 & 97.61 & Lattice & 1 & 0.50 & 97.03 \\
\hline 19 & Warp fiber in color & 1 & 0.34 & 97.95 & Warp fiber in color & 1 & 0.50 & 97.52 \\
\hline 20 & Thin thick warp & 1 & 0.34 & 98.29 & Thin thick warp & 1 & 0.50 & 98.02 \\
\hline 21 & Double warps & 1 & 0.34 & 98.63 & Double warps & 1 & 0.50 & 98.51 \\
\hline 22 & Missing warp & 1 & 0.34 & 98.98 & Missing warp & 1 & 0.50 & 99.01 \\
\hline 23 & Temple mark & 1 & 0.34 & 99.32 & Temple mark & 1 & 0.50 & 99.50 \\
\hline 24 & Hole-tear-burst & 1 & 0.34 & 99.66 & Hole-tear-burst & 1 & 0.50 & 100.00 \\
\hline 25 & $\begin{array}{l}\text { Full-width broken } \\
\text { weft }\end{array}$ & 1 & 0.34 & 100 & Fiber in color & 0 & 0.00 & 100.00 \\
\hline
\end{tabular}

increases. Cotton fibers are shorter than polyester fibers. Moreover, in a group of cotton fibers, fibers of different lengths and thicknesses are present. When this situation is taken into consideration, the unevenness of a thread increases with increment in its cotton content [26]. Thus, specifical defects present on recycled fabrics are half-width broken weft, thin thick weft and fiber in color defects.

Whereas half-width broken defect and thin thick weft defects are caused by yarn unevenness, another special defect found in recycled fabrics is fiber in color. In the first production step of recycled yarn manufacturing which is waste sorting, separation of colored fabric pieces and mixing of colored fibers during sorting are considered to be the reason for this defect.

The stop mark $(11.95 \%)$, broken warp $(11.26 \%)$, fullwidth double wefts $(8.42 \%)$, slub $(5.80 \%)$, bad selvedge $(5.80 \%)$ defects found on $35 \%$ PES $-65 \%$ r-Cotton fabrics are considered as mechanical and labor defects [25]. Consequently, these are defects not related to the production and quality of the recycled yarns but are defects that occur during weaving. The defects, which have been commonly encountered within the scope of this study, are given in figure 3. 


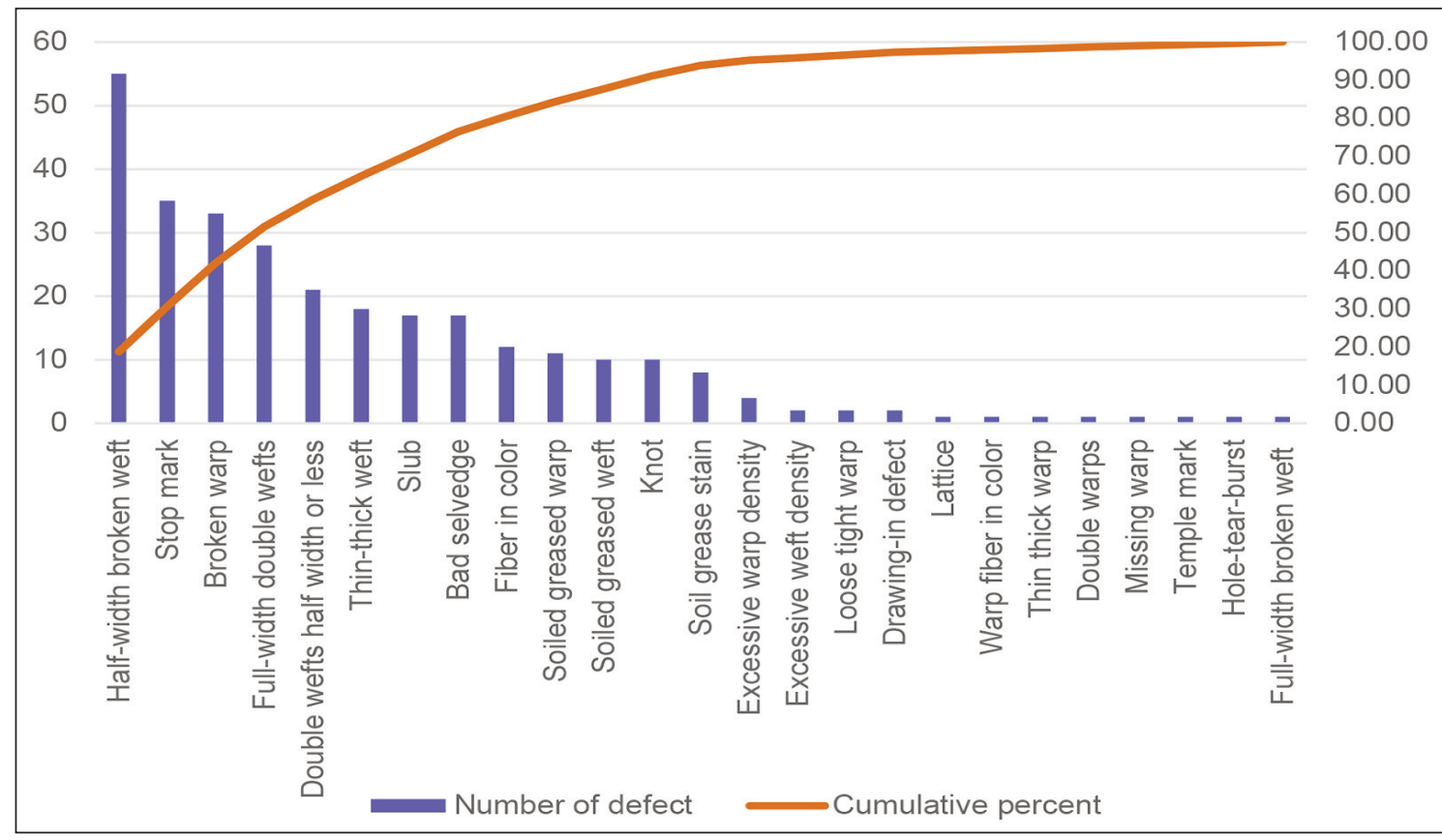

Fig. 1. Pareto diagram showing defect amounts found on 35\% PES-65\% r-Cotton fabrics

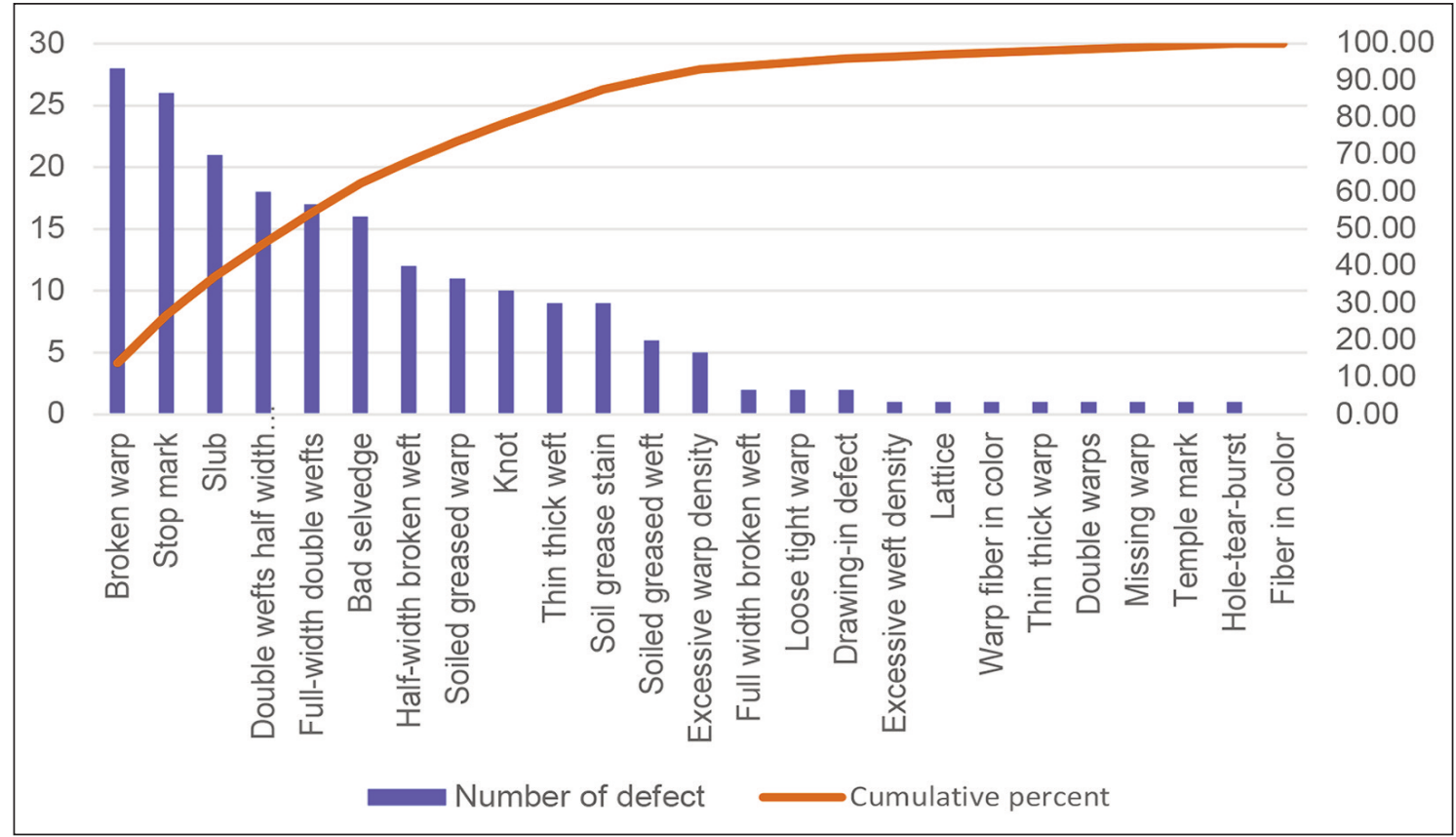

Fig. 2. Pareto diagram showing defect amounts found on $35 \%$ PES- $65 \%$ Cotton fabrics

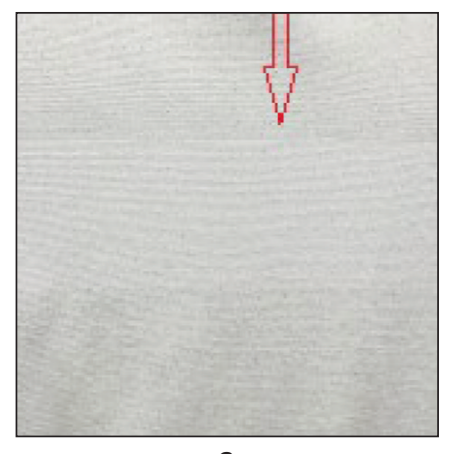

a

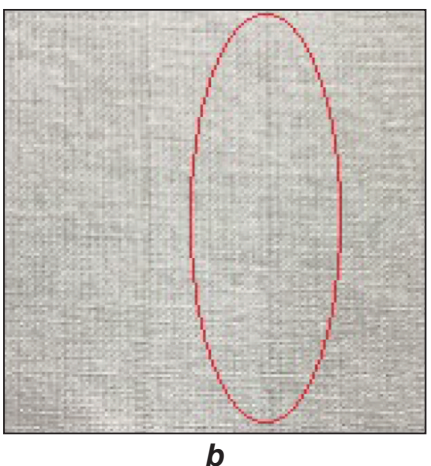

b

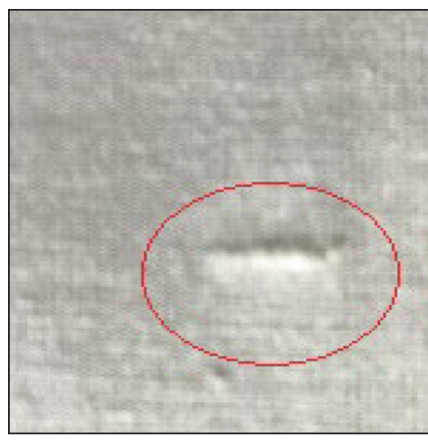

C

Fig. 3. Fabric defects commonly encountered within the scope of this study: a - stop mark; $b$ - broken warp; $c$ - slub 
Apparel manufacturing processes and percentage of second quality products

In total, 17 fabric rolls were sent to the cutting department were spread and cut. The marker efficiency values are given in table 6 . The marker includes each one from four different sizes $(36,38,40,42)$. Each spread included 100 plies. 5 spreads were laid for $53 \%$ PES-65\% r-Cotton and 5 for 35\% PES-65\% Cotton fabrics. Thus, total 10 spreads were laid. When the fabric roll ends, or when a fabric defect has to be cut out, splicing should be carried out to
$4.9 \%$ and $2.75 \%$, respectively. The difference between them is $2.15 \%$.

After the production, the distributions of defects for the second quality products with irreparable defects are shown in table 8 . These defects include cutting -measurement defects, dyeing-printing defects, sewing defects, thread-weaving defects and other defects. According to Table 8, the rates of weaving/ surface defective product in all defects are $78.57 \%$ and $69.09 \%$ for the $35 \%$ PES - 65\% r-Cotton and $35 \%$ PES - 65\% Cotton fabrics, respectively.

CUTTING AND SPREADING INFORMATION OF THE ORDER

\begin{tabular}{|c|c|c|c|c|c|c|c|c|c|c|}
\hline Fabric type & $\begin{array}{c}\text { Total } \\
\text { fabric } \\
\text { (m) }\end{array}$ & $\begin{array}{c}\text { Planned } \\
\text { amount } \\
\text { to be cut }\end{array}$ & $\begin{array}{c}\text { Number } \\
\text { of rolls }\end{array}$ & $\begin{array}{c}\text { Number } \\
\text { of } \\
\text { spreads }\end{array}$ & $\begin{array}{c}\text { Assort- } \\
\text { ment }\end{array}$ & \multicolumn{4}{|c|}{ CAD Efficiency } \\
(\%)
\end{tabular}

\begin{tabular}{|c|c|c|c|c|c|c|}
\hline \multicolumn{1}{|c|}{ REALIZED ORDER INFORMATION } \\
\hline Fabric type & $\begin{array}{c}\text { Total fabric } \\
\text { length } \\
\text { ( } \mathbf{m})\end{array}$ & $\begin{array}{c}\text { Planned } \\
\text { amount } \\
\text { to be cut }\end{array}$ & $\begin{array}{c}\text { Splicing } \\
\text { number }\end{array}$ & $\begin{array}{c}\text { First quality } \\
\text { (number) }\end{array}$ & $\begin{array}{c}\text { Second } \\
\text { quality } \\
\text { (number) }\end{array}$ & $\begin{array}{c}\text { Second quality } \\
\text { percentage in the } \\
\text { order (\%) }\end{array}$ \\
\hline $35 \%$ PES-65\% r-Cotton fabric & 2372 & 2000 & 43 & 1902 & 98 & 4.9 \\
\hline $35 \%$ PES-65\% Cotton fabric & 2360 & 2000 & 29 & 1945 & 55 & 2.75 \\
\hline
\end{tabular}

\begin{tabular}{|c|c|c|c|c|c|c|c|}
\hline \multicolumn{7}{|c|}{ THE DEFECTIVE PRODUCT DISTRIBUTION IN THE ORDER } \\
\hline Fabric type & $\begin{array}{c}\text { Cutting/ } \\
\text { measurement } \\
\text { defects } \\
\text { (number) }\end{array}$ & $\begin{array}{c}\text { Dyeing/ } \\
\text { printing } \\
\text { defect } \\
\text { (number) }\end{array}$ & $\begin{array}{c}\text { Sewing } \\
\text { defect } \\
\text { (number) }\end{array}$ & $\begin{array}{c}\text { Weaving/ } \\
\text { surface } \\
\text { defect } \\
\text { (number) }\end{array}$ & Others & $\begin{array}{c}\text { Second } \\
\text { quality } \\
\text { (number) }\end{array}$ & $\begin{array}{c}\text { Second quality } \\
\text { rate based on } \\
\text { weaving (\%) }\end{array}$ \\
\hline $\begin{array}{c}35 \% \text { PES-65\% } \\
\text { r-Cotton fabric }\end{array}$ & 13 & 4 & 1 & 77 & 3 & 98 & 78.57 \\
\hline $\begin{array}{c}35 \% \text { PES-65\% } \\
\text { Cotton fabric }\end{array}$ & 11 & 3 & 2 & 38 & 1 & 55 & 69.09 \\
\hline
\end{tabular}

avoid incomplete fabric pieces. For 35\% PES-65\% r-Cotton and 35\% PES, 65\% Cotton fabrics 43 and 29 splicing actions were carried out respectively. For each splicing, the overlapping fabric length was between 20 and $60 \mathrm{~cm}$. Once spreading and cutting oprations have been completed, the enumerated product pieces were bundled, labeled and dispatched to the sewing room. After the sewing processes, $100 \%$ product quality inspection was carried out and the first and second quality items were separated.

In table 7, the first and second quality ratios obtained at the end of production are given. According to this, the second quality product ratio for $35 \%$ PES $-65 \%$ r-Cotton and 35\% PES-65\% r-Cotton fabrics are

\section{CONCLUSIONS}

This study has been conducted in order to define and determine defects encountered in weaving and apparel production processes of fabrics manufactured from recycled yarns and equivalent original yarns.

After weaving, 293 defects have been reported in 2372 meters of fabric produced by using 35\% PES $65 \%$ r-cotton yarn in weft and 202 defects have been reported in 2360 meters of fabric produced by using $35 \%$ PES - $65 \%$ cotton yarn in weft. After the production, it was seen that the ranking of defect types shows difference between 35\% PES - 65\% r-Cotton and $65 \%$ Cotton fabrics. By use of Pareto analysis 
technique, a number of defect types have been arranged in terms of their prominence. By this means, the most important fabric defects in recycled fabrics have been determined. The specific defect types confronted in recycled fabrics have been observed as half-width broken weft defect, thin-thick weft defect and fiber in color defect. It is not possible to avoid all fabric defects found during woven fabric quality inspection. However, it is necessary to carefully plan arrangements and developments related to recycled yarn manufacturing which is the first step of production in order to take the process under control and to attain required product quality. It is impossible to avoid all undesired fabric defects in the final product before their occurrence. However, via reduction of defective production, the require product quality can be achieved and operating costs can be substantially decreased.

At the end of apparel production, the fabric/surface defective product rates in all defects for 35\% PES $65 \%$ r-Cotton and 35\% PES - 65\% Cotton fabrics were $78.57 \%$ and $69.09 \%$, respectively. The fabric/ surface defective product increase in shirts produced from $35 \%$ PES - 65\% r-Cotton fabrics was $9.48 \%$. At the end of the production, percentage of the second quality products for 35\% PES - 65\% r-Cotton and $35 \%$ PES - $65 \%$ Cotton fabrics were $4.9 \%$ and
$2.75 \%$, respectively. When the two fabrics produced at the same construction, under the same conditions and in the same factory, are compared, it can be said that the difference stems from recycled threads. However, when the positive environmental contributions and economical advantages of recycled yarns are taken into consideration, this difference should be ignored.

Based on its positive effect on the price and environment, the importance of yarn and fabric production from recycled raw material is growing day by day. Nevertheless, standardization of quality is needed for recycled yarns. More research study is necessary related to production of higher quality recycled yarns and fabrics more efficiently.

It is suggested that determination of various mechanical and physical properties of fabrics produced from recycled yarns of different fiber blends and blend ratios and improvement of these properties can be the subject of future research.

\section{ACKNOWLEDGEMENT}

The author acknowledges employees and directors of CNF Tekstil and Osman Canlı Tekstil who contributed to the experimental work.

\section{REFERENCES}

[1] Eser, B., Çelik, P., Çay, A., Akgümüş, D., Sustainability and Recycling Opportunities in the Textile and Apparel Sector, In: Journals of Textiles and Engineer, 2016, 23, 101, 43-60

[2] Altun, Ş., Recycling of Textile Pre-consumer and Post-Consumer Wastes and Its Environmental and Economical Effects, Uşak Ticaret ve Sanayi Odası Raporu, 2016

[3] Güngör, A., Palamutçu, S., İkiz, Y., Cotton Textiles and the Environment: Life Cycle Assessment of a Bathrobe, In: Textile and Apparel, 2009, 19, 3, 197-205

[4] Merati, A.A., Okamura, M., Producing Medium Count Yarns from Recycled Fibers with Friction Spinning, In: Text. Res. J., 2004, 74, 7, 640-645

[5] Altun, Ş., Revealing the General Profile of the Textile and Garment Waste and Recycling Facility in Turkey, Project no. 109Y008, 2010

[6] Wulfhorst, B., Textile Technology, Translation Demir, A, Torun, A.R., İstanbul, 2003, 295-300

[7] Umar, M., Shaker, K., Ahmad, S., Nawab, Y., Umair, M., Maqsood, M., Investigating the Mechanical Behavior of Composites Made from Textile Industry Waste, In: The Journal of The Textile Institute, 2017, 108, 5, 835-839

[8] Bjo, S., Aronsson, J., Henriksson, G., Persson, A., Textile Qualities of Regenerated Cellulose Fibers from Cotton Waste Pulp, In: Textile Research Journal, 2018, 88, 21, 2485-2492

[9] Silva, R., Byrne, N., Utilization of Cotton Waste for Regenerated Cellulose fibres: Influence of Degree of Polymerization on Mechanical Properties, In: Carbohydrate Polymers, 2017, 174, 89-94

[10] Inoue, M., Yamamoto, S., Performance and Durability of Woven Fabrics Including Recycled Polyester Fibers, In: Journal of Textile Engineering, 2004, 50, 2, 25-30

[11] Larney, M., Van Aardt, A.M, Case study: Apparel Industry Waste Management: A Focus on Recycling In South Africa, In: Waste Management \& Research, 2010, 28, 36-43

[12] Zoua, Y., Reddya, N., Yang, Y., Reusing Polyester/Cotton Blend Fabrics for Composites, In: Composites Part B: Engineering, 2011, 42, 4, 4, 763-770

[13] Duru, P.N., Babaarslan, O., Determining an Optimum Opening Roller Speed for Spinning Polyester/Waste Blend Rotor Yarns, In: Textile Research Journal, 2003, 73, 10, 907-911

[14] El-Nouby, G.M., Hairiness of Yarns Made of Recycled Waste Fabric, In: J. Appl. Sci. Res., 2007, 3, 10, $972-976$

[15] Halimi, T.M., Ben Hassen, M., Azzouz, B., Sakli, F., Effect of Cotton Waste and Spinning Parameters on Rotor Yarn Quality, In: Journal of The Textile Institute, 2007, 98, 437-442

[16] Kaplan, S., Göktepe, Ö., Investigation into Navel Selection for Rotor Spinning Machine Using Cotton Waste, In: Fibres \& Textiles in Eastern Europe, 2006, 14, 3, 58-62 
[17] Wanassi, B., Azzouz, B., Hassen, M.B., Recycling of Post-industrial Cotton Wastes: Quality and Rotor Spinning of Reclaimed Fibers, In: International Journal of Advanced Research, 2015, 3, 6, 94-103

[18] El-Nouby, G.M., Recycled Yarn from Textile Waste - Part I: Recycled Yarn Hairiness, In: Egy. J. Text. \& Polym. Sci. \& Tech., 2006, 11

[19] Ala, D.M., İkiz, Y., Defect Detection of Velvet Bathrobe Fabrics and Grading with Demerit Point Systems, In: Pamukkale University Journal of Engineering Sciences, 2015, 21, 7, 288-295

[20] Ala, D.M., İkiz, Y., A Statistical Investigation for Determining Fabric Defects That Occur During Weaving Production, In: Pamukkale University Journal of Engineering Sciences, 2015, 21, 7, 282-287

[21] Kısaoğlu, Ö., Fabric Quality Control Systems, In: Pamukkale University Journal of Engineering Sciences, 2006, 12, 2, 233-241

[22] Patır, S., İstatistiksel Proses Kontrol Teknikleri ve Kontrol Grafiklerinin Malatya'daki Bir Tekstil (İplik Dokuma) Işletmesinde Bobin Sarım Kontrolüne Uygulanması, In: The Journal of Social Economic Research., 2009, 9, 18, 231-249

[23] Dülgeroğlu, K.Ö., A Statistical Quality Control System in a Medium-Scale Weaving Mill: II. Control of Loom Stoppages, In: Pamukkale University Journal of Engineering Sciences, 2010, 16, 3, 303-313

[24] Dülgeroğlu, K.Ö., A Statistical Quality Control System in a Medium-Scale Weaving Mill: I. Control of Fabric Defects, In: Pamukkale University Journal of Engineering Sciences, 2010, 16, 3, 291-301

[25] Turkish Standards Institute, Definition and Terminology Relating to Woven Fabric Defects, Ankara, Türkiye, TS 471 ISO 8498, 2005

[26] Ersoy, Y., Şenol, M.F., Type of Raw Material and Production Parameters Effect on Yarn Quality: An Application on Open-End Spinning, In: The Journal of Graduate School of Natural and Applied Sciences of Mehmet Akif Ersoy University, 2017, 8, 1, 96-107

Author:

KALKANCI MIHRIBAN

Pamukkale University, Denizli Vocational School of Technical Sciences,

Camlaraltı Mah. Fakülte Cad. no. 30, 20160, Kınıkı/Denizli, Turkey

Corresponding author:

KALKANCI MIHRIBAN

e-mail: mkalkanci@pau.edu.tr 